\title{
Chronic hepatitis $B$ genotype $E$ in African migrants: response to nucleos(t)ide treatment in real clinical practice
}

\author{
José Ángel Cuenca-Gómez ${ }^{1 *}$ (D), Ana Belén Lozano-Serrano', María Teresa Cabezas-Fernández',
} Manuel Jesús Soriano-Pérez ${ }^{1}$, José Vázquez-Villegas² ${ }^{2}$ Matías Estévez-Escobar ${ }^{3}$, Isabel Cabeza-Barrera ${ }^{1}$ and Joaquín Salas-Coronas ${ }^{1}$

\begin{abstract}
Background: Hepatitis B virus (HBV) genotype E is a poorly studied genotype that almost exclusively occurs in African people. It seems to harbour intrinsic potential oncogenic activity and virological characteristics of immune scape but a paucity of information is available on clinical and virological characteristic of HBV genotype E-infected patients as well as on the efficacy of anti-HBV drugs for such patients. The increasing flow of migrants from high endemic HBV sub-Saharan Africa, where genotype $\mathrm{E}$ is the predominant one, to Western countries makes improving such knowledge critical in order to deliver proper medical care.
\end{abstract}

Methods: Prospective observational study of naïve patients of sub-Saharan origin treated for chronic HBV genotype $\mathrm{E}$ infection at a Tropical Medicine clinic sited in Spain from February 2004 to January 2018. The aim of the study was to describe the response of chronic HBV genotype $\mathrm{E}$ infection to nucleos(t)ide analogues (NA), entecavir or tenofovir, in real clinical practice.

Results: During the study period, 2209 sub-Saharan patients were assisted at our Tropical Medicine Unit and 609 (27.6\%) had chronic HBV (CHB) infection. Genotype information was available for 55 naïve patients initiating treatment with NA (entecavir or tenofovir), 43 (84.3\%) of them being genotype E, although 15 were excluded because they did not meet study inclusion criteria. Thus, a total of 28 CHB genotype E patients were included and followed for 24 months at least. Twenty-one patients were in HBeAg-negative chronic hepatitis phase and 7 patients in HBeAgpositive chronic hepatitis phase. After one year of treatment, among those with good adherence, $89.4 \%$ (17/19) of the HBeAg-negative patients and $80 \%$ of the HBeAg-positive ones had undetectable viral loads. Response rates reached $100 \%$ in both groups after 15-18 months of follow-up. Out of the 7 HBeAg-positive patients, 6 (85.7\%) presented HBeAg loss in a median time of 31.8 months. Neither serious adverse effects nor hepatocarcinoma cases happened during the study period.

Conclusions: HBV genotype may influence disease progression and antiviral response. Our study provides precious information on the efficacy and safety of NA treatment for CHB genotype E infection, a fairly unknown genotype with and increasing epidemiological impact.

Keywords: Hepatitis B, Genotype E, Tenofovir, Entecavir, African migrants

\footnotetext{
* Correspondence: jacuencag@gmail.com

${ }^{1}$ Tropical Medicine Unit, Hospital de Poniente, Carretera de Almerimar s/n,

PD: 07400 Almería, El Ejido, Spain

Full list of author information is available at the end of the article
}

(c) The Author(s). 2018 Open Access This article is distributed under the terms of the Creative Commons Attribution 4.0 International License (http://creativecommons.org/licenses/by/4.0/), which permits unrestricted use, distribution, and reproduction in any medium, provided you give appropriate credit to the original author(s) and the source, provide a link to the Creative Commons license, and indicate if changes were made. The Creative Commons Public Domain Dedication waiver (http://creativecommons.org/publicdomain/zero/1.0/) applies to the data made available in this article, unless otherwise stated. 


\section{Background}

Hepatitis B virus (HBV) chronic infection is a very prevalent disease worldwide. It is estimated that more than 240 million people are infected and that around 686,000 people annually die from complications of this disease, including liver cirrhosis and hepatocarcinoma [1].The vast majority of them live in low- and middle-income regions such as sub-Saharan Africa, where roughly more than 50 million people are infected.

Hepatitis B could be considered, in some parts of the world, a neglected disease for a number of reasons [2]:the major burden of morbidity and mortality from $\mathrm{HBV}$ is borne by tropical and subtropical countries; HBV infection is a silent disease leading to a large pool of undiagnosed infection; it disproportionately affects populations living in poverty; it causes stigma and discrimination; lack of public/media representation because HBV is "eclipsed" by higher profile infections such as HIV or malaria; lack of existing investment and development of infrastructure through which to provide education, prevention, diagnosis, and treatment; poor-quality data contributing to misinformation about epidemiology and risk factors and lack of assessment regarding feasibility of interventions; and, finally, lack of major dedicated funding agencies. As a result, mortality due to viral hepatitis (HBV and HCV) is increasing while mortality from other diseases such as HIV and malaria has declined [3].

To date, 10 genotypes (A-J) and more than 40 sub-genotypes have been identified for HBV. The distribution of HBV genotypes differs throughout the world [4]: genotypes A and D are the most prevalent in Europe; D in Asia; B, D and G in North America; F in South America; and $\mathrm{E}$ in sub-Saharan Africa, comprising up to $70 \%$ of all African HBV-infected patients.

HBV genotype may influence disease progression and antiviral response [5] and there are numerous studies related to such aspects: evolution of the disease according to genotype or risk of chronicity [6-9]; percentage of HBeAg or HBsAg loss [10, 11]; HBV DNA levels [12$15]$; risk of progression of liver disease $[16,17]$ and risk of hepatocellular carcinoma [18-20]; and response to treatment [21-25]. However, most studies are performed on genotypes $\mathrm{A}, \mathrm{B}, \mathrm{C}$, and $\mathrm{D}$.

Although it seems to harbour intrinsic potential oncogenic activity and virological characteristics of immune scape [26], there is limited literature on the natural course of HBV genotype E chronic infection, and even fewer studies addressing its response to antiviral treatment.

A search in PUBMED with the commands "hepatitis B" AND "genotype E", without any type of filter, retrieved 141 articles. Of these, only 10 [12, 27-35] (7.1\%) describe genotype $\mathrm{E}$ response to treatment in a variety of distinct scenarios: HIV-HBV co-infected patients [27-30], rescue after lamivudine failure [31], adefovir phase III clinical trials including a total of 6 genotype $E$ patients [12]; response to interferon [33, 34] and a follow-up study of HBsAg decline in entecavir-responding patients [32]. Finally, one retrospective study addresses $\mathrm{HBV}$ genotypes E-H response to antiviral therapy in naïve mono-infected patients but includes just 6 genotype $E$ patients treated with nucleos(t)ide analogues [35]. Current international guidelines do not consider either patients with HBV-genotype E chronic hepatitis [36].

$\mathrm{HBV}$ genotype $\mathrm{E}$ almost exclusively occurs in African people but due to the significant migratory flow from sub-Saharan countries that has occurred in Europe in recent years, an increasing number of patients with chronic HBV hepatitis are been treated and followed up [37]. In some studies, more than $80 \%$ of these patients had a genotype $\mathrm{E}$ [38]. A better knowledge of the evolution of $\mathrm{CHB}$ genotype $\mathrm{E}$ infection and its response to treatment is of great importance when making recommendations that could differ from those issued for other genotypes, in order to deliver proper medical care.

Our Tropical Medicine Unit (TMU) belongs to the Hospital of Poniente, sited in the province of Almeria, in Southern Spain. It serves a population of about 270,000 people, of which around $30 \%$ are immigrants, with a high proportion of people coming from West African countries. Chronic hepatitis B is one of the most prevalent infectious diseases among immigrant patients, especially among those of sub-Saharan origin [39].

The aim of this study is to analyze the response to treatment with NA (entecavir or tenofovir) in sub-Saharan patients with $\mathrm{CHB}$ genotype $\mathrm{E}$ infection in real world practice.

\section{Methods}

\section{Study design}

Prospective observational study intended to describe virological outcome of naïve African patients with $\mathrm{CHB}$ genotype $\mathrm{E}$ infection treated with NA in real clinical practice.

\section{Study population and data collection}

The study was carried out at the TMU of the Hospital of Poniente from February 2004 to January 2018. The following inclusion criteria were followed: i) $\mathrm{CHB}$ genotype $\mathrm{E}$ infection; ii) absence of coinfection with human immunodeficiency, hepatitis $C$ or hepatitis D viruses, and absence of any other liver disease, such as autoimmune hepatitis; iii) individual follow-up for at least 24 months.

Decision to start HBV treatment was based on current recommendations of the European Association for the Study of Liver on force at the time $[40,41]$. The choice of starting treatment with tenofovir or entecavir was at the discretion of the physician responsible for the patient, except in the presence of impaired renal function, where entecavir was used. On the contrary, all women 
of reproductive age were treated with tenofovir. Treatment with INF/PEG-INF was not considered because, although the available information is truly scarce, a recent study has shown poor response to interferon-based treatment in patients with chronic HBV genotype E infection [34], and also because of a less favourable tolerability-security profile as compared to NA treatment, specially for the migrant population, often conditioned by language barrier, infectious co-morbidities and poor socio-economic status.

For each included patient, laboratory and imaging data were prospectively registered. Data were analysed anonymously.

\section{Laboratory data}

Serum samples were evaluated for the presence of HBsAg, anti-HBc and anti-HBs. When HBsAg was detected, $\mathrm{HBeAg}$ and anti-HBe were determined. Patients with $\mathrm{HBsAg}$ and anti-HBe positivity, viral load under $2000 \mathrm{IU} / \mathrm{mL}$, and persistently normal transaminase levels were defined as inactive chronic carriers. The remaining patients with $\mathrm{HBsAg}$ positivity were classified either as HBeAg-positive chronic hepatitis (HBeAg-positive, anti-HBe-negative), or HBeAg-negative chronic hepatitis (HBeAg-negative, anti-HBe-positive), following the criteria of the European Association for the Study of the Liver on force [40, 41]. In HBsAg-positive patients, the quantification of HBV-DNA was performed by real-time PCR (COBAS Amplipre / CobasTaqman-Roche Diagnostics), with a limit of detection of $10 \mathrm{IU} / \mathrm{ml}$. HBV genotype was determined by partial amplification and sequencing of the HBsAg coding gene.

\section{Follow-up}

Visits were scheduled every 3 months, during the first year and afterwards. Viral load was programmed to be determined at months 3, 6 and 12 months, and every 6 months from there on. The evolution of alanine aminotransferase (ALT) and HBV-DNA viral load were analysed. Normal ALT was defined as $\leq 30 \mathrm{IU} / \mathrm{L}$ in men and $\leq 19 \mathrm{IU} / \mathrm{L}$ in women [42]; and undetectable viral load as HBV-DNA $<10 \mathrm{IU} / \mathrm{mL}$.

As an actual clinical practice study, determination of HBV viral load was adapted to whenever patients came to the clinic, trying to roughly follow the aforementioned scheme. For those visits with no viral load available, it was assumed that it was detectable if it was detectable at the previous and subsequent visits ( \pm 3 months), and undetectable if it was so at the previous and subsequent ones ( \pm 3 months).

All patients underwent a liver ultrasound before treatment and every 6 months thereafter. An ultrasoundguided liver biopsy was performed in those patients presenting any medical reason for. METAVIR classification was used for classification of liver fibrosis and activity grade [43].

To evaluate adherence to treatment, clinical interview at every scheduled visit to the clinic and verification of patients' drug withdrawal from the hospital pharmacy were used. To assess the safety of the treatment, urine sediment and dipstick analysis, glomerular filtration and plasma phosphorus level were measured at each visit.

\section{Statistical analysis}

A descriptive statistical analysis was performed where continuous variables were expressed as medians and interquartile ranges (IQR), and categorical variables were described using a table of frequencies and proportions. STATA version 12 was the statistical program used to analyse the data.

\section{Literature review}

To analyse the relevance of genotype $\mathrm{E}$ in the literature, a bibliographic search was carried out in PUBMED using the commands "hepatitis B" AND "genotype E", without any type of filter.

\section{Results}

During the study period, a total of 2209 sub-Saharan patients were assisted at the TMU; 609 (27.6\%) of them presented CHB infection: 370 (60.7\%) were classified as inactive chronic carriers, $181(29.7 \%)$ were in a chronic HBeAg-negative phase, and 58 (9.5\%) in a chronic HBeAg-positive phase. Treatment was initiated in 72 patients; genotype information was available in 55 of them: 43 (84.3\%) genotype E, 6 genotype A, and 2 genotype D. Finally, out of the 43 patients with genotype E, 15 were excluded because they did not meet the inclusion criteria of the study. Thus, a total of 28 patients were included.

\section{Demographic data}

Out of the 28 patients, 24 (85.7\%) were men and the median age was 31.5 years (IQR 8). Median length of stay in Spain was 54 months (IQR 49). The countries of origin were Mali (7 patients), Guinea-Bissau (7 patients), Senegal (5 patients), Guinea-Conakry (3 patients), Ghana (3 patients), and Gambia, Nigeria and Burkina Faso (1 patient each).

\section{Hepatitis B laboratory data results}

Twenty-one patients were in $\mathrm{HBeAg-negative} \mathrm{chronic}$ hepatitis phase and 7 patients in $\mathrm{HBeAg-positive} \mathrm{chronic}$ hepatitis phase; 26 patients $(92.9 \%)$ presented abnormal elevated ALT measurements before starting treatment. Median ALT in HBeAg-negative patients was $64.5 \mathrm{IU} / \mathrm{L}$ (IQR 119), and 84 IU/L (IQR 61) in HBeAg-positive patients. One hundred per cent of patients had detectable viral load at the time of treatment initiation. Median 
viral load at the start of treatment for HBeAg-negative patients was $5.28 \operatorname{logIU} / \mathrm{mL}$ (IQR 6.26), and $7.23 \operatorname{logIU} / \mathrm{mL}$ (IQR 5.23) for HBeAg-positive patients. Baseline characteristics at the start of treatment are described in Table 1.

\section{Ultrasound and biopsy findings}

Hepatic ultrasonography was abnormal (showing signs of chronic liver disease) in 5 patients (17.9\%). Hepatic biopsy was performed in 10 patients: 3 had stage A1F1, 3 patients A1F2, 1 patient A2F1, 1 patient A2F2, 1 patient A3F2, and 1 patient A3F3, as for METAVIR classification.

\section{Treatment outcome and follow-up}

Treatment with tenofovir $245 \mathrm{mg} /$ day was initiated in 24 patients (17 HBeAg-negative and $7 \mathrm{HBeAg}$-positive), and with entecavir $0.5 \mathrm{mg} /$ day in 4 patients (all of them HBeAg-negative).

During the first year of follow up, $93 \%$ of patients had good adherence, attending to scheduled visits regularly and showing good treatment compliance. This figure almost reached $100 \%$ during the second year.

For the analysis of the evolution of ALT levels and viral load, only those patients who showed good adherence to the treatment were selected $(20 \mathrm{HBeAg}$-negative

Table 1 Baseline characteristics at the start of treatment

\begin{tabular}{|c|c|c|}
\hline & $\begin{array}{l}\text { HBeAg- } \\
\text { positive }\end{array}$ & HBeAg-negative \\
\hline $\begin{array}{l}\text { Number of patients: } \\
\mathrm{N}(\%)\end{array}$ & $7(25 \%)$ & $21(75 \%)$ \\
\hline Age $(\text { years) })^{a}$ & $24(8)$ & $33(7)$ \\
\hline Male sex: N (\%) & $5(71.4 \%)$ & 19 (90.5\%) \\
\hline $\begin{array}{l}\text { Mean length of stay } \\
\text { in Spain (months) }\end{array}$ & $11(72)$ & $69(28)$ \\
\hline Co-morbidities & None & $\begin{array}{l}\text { Coinfection with S. mansoni } \\
\text { ( } 2 \text { patients) Fatty liver (1 patient) }\end{array}$ \\
\hline $\operatorname{ALT}(I U / L)^{a}$ & $84(61)$ & $64.5(119)$ \\
\hline AST $(I U / L)^{a}$ & $62(26)$ & $56.5(93)$ \\
\hline $\mathrm{GGT}(\mathrm{IU} / \mathrm{L})^{\mathrm{a}}$ & $30(41)$ & $48.5(34)$ \\
\hline $\operatorname{ALP}(I U / L)^{a}$ & $104(66)$ & $92(35)$ \\
\hline Total bilirubin $(\mathrm{mg} / \mathrm{dL})^{a}$ & $0.4(0.2)$ & $0.66(0.93)$ \\
\hline Platelets $\times 10^{3} \mu \mathrm{L}^{\mathrm{a}}$ & $204(97)$ & $168.5(111)$ \\
\hline Prothrombin time (\%) ${ }^{a}$ & $78(18)$ & $90.5(20.3)$ \\
\hline $\begin{array}{l}\text { Alpha-fetoprotein } \\
(\mathrm{ng} / \mathrm{mL})^{\mathrm{a}}\end{array}$ & $4.6(3.6)$ & $2.5(1.4)$ \\
\hline HBV-DNA $(\log I U / m L)^{a}$ & $7.23(5.23)$ & $5.28(6.26)$ \\
\hline FIB- 4 score ${ }^{a}$ & $0.8(1.8)$ & $1.5(0.9)$ \\
\hline APRI score ${ }^{a}$ & $0.9(1.2)$ & $1(1.7)$ \\
\hline Chosen treatment & $\begin{array}{l}\text { Tenofovir } \\
\text { (7 patients) }\end{array}$ & $\begin{array}{l}\text { Tenofovir (17 patients) Entecavir } \\
\text { (4 patients) }\end{array}$ \\
\hline
\end{tabular}

${ }^{a}$ Values are median and (IQR). ALT Alanine aminotransferase, AST Aspartate aminotransferase, GGT Gamma-glutamyl transferase, ALP Alkaline phosphatase. FIB-4 score: Fibrosis-4 score. APRI score: AST to Platelet Ratio Index patients and $6 \mathrm{HBeAg}$-positive). The proportions of compliant patients with normal ALT or undetectable viral load in each visit are shown in Figs. 1 and 2. After two years of treatment, $66.7 \%$ of $\mathrm{HBeAg}$-positive patients and $45 \%$ of $\mathrm{HBeAg}$-negative ones had normalized transaminases. ALT figures may have been influenced by the fact that two patients were coinfected by $S$. mansoni and one patient had a fatty liver. After one year of treatment, $89.4 \%$ (17/19) of HBeAg-negative compliant patients had an undetectable viral load, rising to $100 \%$ at month 15. In the case of HBeAg-positive compliant patients, $80 \%$ had an undetectable viral load after one year of treatment, and $100 \%$ at 18 months.

Of the $7 \mathrm{HBeAg}$-positive patients, 6 (85.7\%) presented HBeAg loss (5 with anti-HBe seroconversion) in a mean time of 31.8 months. No HBsAg loss happened during follow-up in any patient. No cases of hepatocarcinoma were detected during the study period.

There were not any serious adverse reactions during the whole follow-up period. Only 6 cases of mild and self-limited hypophosphatemia were detected in tenofovir treated patients, none of them requiring discontinuation of the drug. None of the tenofovir treated patients presented evidence of impaired renal function.

\section{Discussion}

With the data we provide, we can state that treatment with nucleos(t)ide analogues in sub-Saharan patients with $\mathrm{CHB}$ genotype $\mathrm{E}$ infection have at least as favorable results as the ones reported for other genotypes, in terms of virological response rates, normalization of transaminases, and loss of HBeAg.

These finding are relevant because sub-Saharan people are one of the populations with the highest prevalence of HBV infection of the world, and genotype E in particular is highly endemic in most of sub-Saharan Africa. Even though HBV genotype E horizontal transmission is also possible, among the migrant population coming from sub-Saharan Africa the infection is most frequently acquired vertically at birth or during the first years of life as a consequence of traditional medicine practices and tribal scarifications [44]. This fact means that, although our patients were fairly young (mean age 31.5 years), HBV infection has probably been present for all that long.

There are many studies relating to chronic hepatitis B infection in recent years but a paucity of information is available on the clinical and virological characteristics of HBV genotype E-infected patients as well as on the efficacy of anti-HBV drugs. Epidemiological studies have suggested the carcinogenic potential of genotype $E$, and in fact, African regions in which genotype $E$ is endemic are characterized by a higher incidence of hepatocellular carcinoma. Although the mechanisms underlying this 


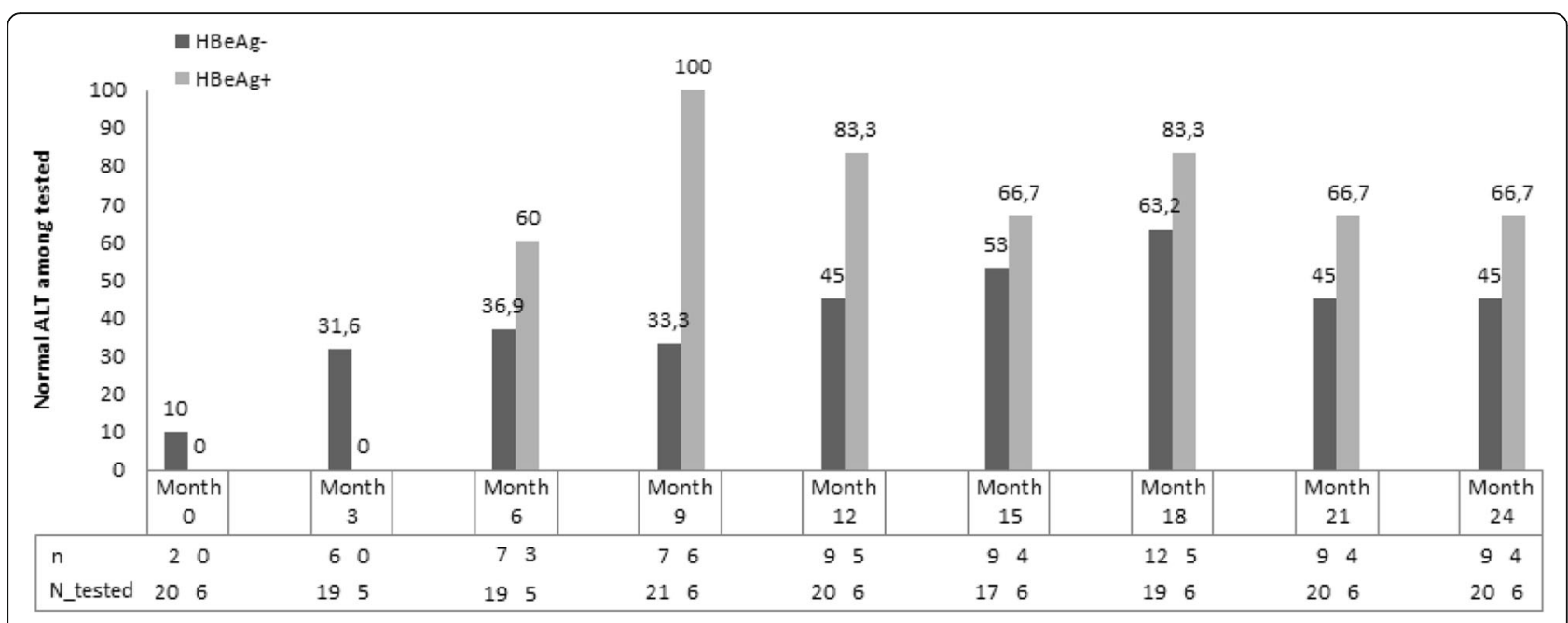

Fig. 1 Percentage of compliant patients with normal alanine aminotranferase (ALT) levels at the different months of follow-up

hypothetic oncogenic potential have not yet been clarified, they could be related to immune escape phenomena [26] as well as to other possible variables involved, such as HIV co-infection, dietary iron overload or aflatoxins consumption [45].

As there is a growing migration movement from these African regions to western countries [46], dealing with migrant patients with hepatitis B genotype $\mathrm{E}$ is becoming more frequent in western hepatology clinics and hospitals. Out of the actual clinical practice studies, only the studies by Marcellin [47] et al. and Boglione et al. $[32,34]$ include a considerable number of sub-Saharan patients, although in Marcellin's study no genotype information is available.

HBV genotype may influence antiviral response, but the main studies that analyze the role of HBV genotype in the treatment with NA mostly deal with genotypes A,
$\mathrm{B}, \mathrm{C}$ and $\mathrm{D}[5,48]$. The importance of our work is that, to our knowledge, is the first prospective clinical practice study truly exploring the virological response to NA therapy in CHB genotype E patients.

There is one clinical practice study about treatment of CHB genotype E patients with NA [32], but it is focused in the decrease of HBsAg titles. In this work, the authors conclude that the decrease of HBsAg titles is smaller in the 34 patients infected by genotype $\mathrm{E}$ as compared to patients infected by genotypes $\mathrm{A}$ or $\mathrm{D}$, although the analysis only included those patients who had achieved previously virological response (HBV-DNA undetectable after 24 weeks of therapy), and the meaning of HBsAg-title changes in this setting is still unclear. Another study with genotype E-infected patients, also conducted by Boglione et al. [34], explores the response to interferon therapy finding very low rates of response;

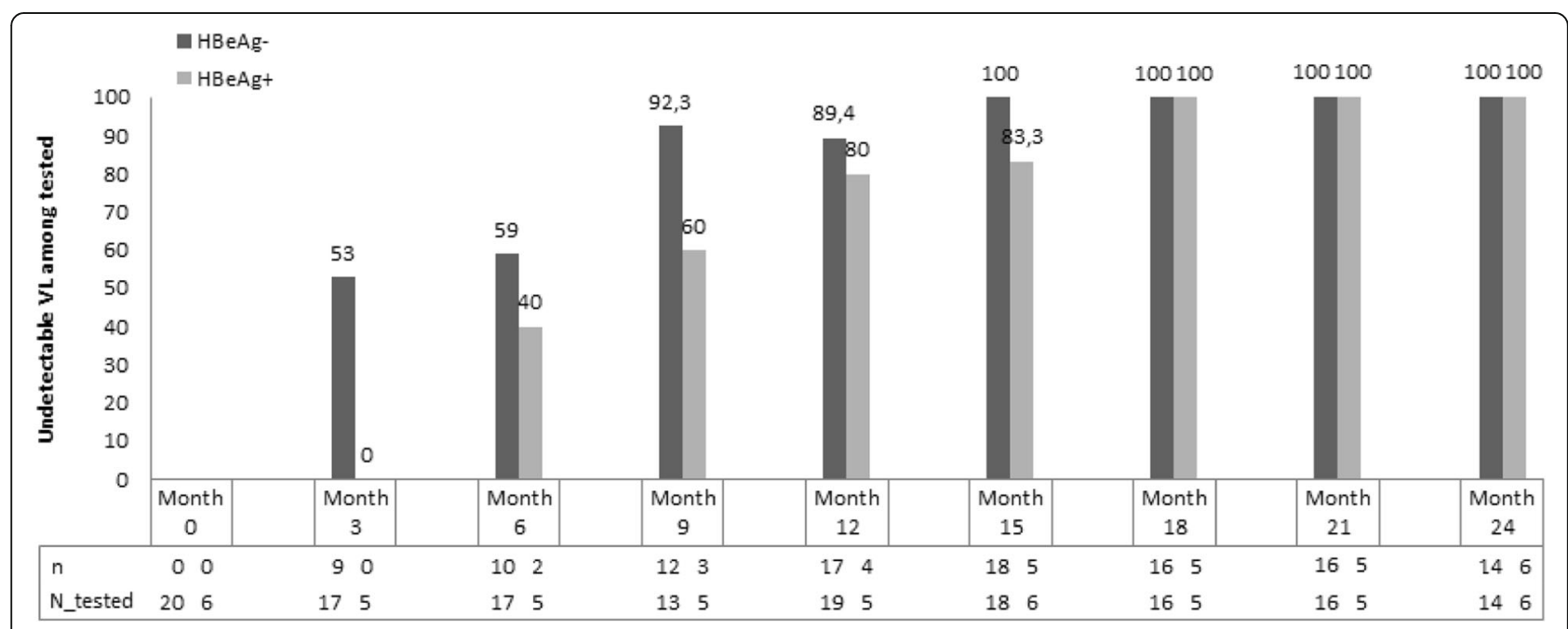

Fig. 2 Percentage of compliant patients with undetectable viral load (VL) at the different months of follow-up 
10 patients were rescued with entecavir after failing interferon treatment and virological response was achieved in $60 \%$ of them after a follow-up median of 5.2 months. There is also one retrospective study that addresses HBV genotypes E-H response to antiviral therapy in naïve mono-infected patients, but includes just 6 genotype $\mathrm{E}$ patients treated with nucleos(t)ide analogues [35]. Current international guidelines do not yet mention patients with HBV-genotype E chronic hepatitis [36].

Finally, a handful of articles deal with $\mathrm{CHB}$ genotype $\mathrm{E}$ patients and NA treatment in different clinical scenarios, like HIV-HBV co-infected patients [27-30], rescue after lamivudine failure [31], and the phase III studies of adefovir dipivoxil reported by Westland et al. [12] where 6 patients with genotype $\mathrm{E}$ were included.

In our study we have included 28 treatment-naive patients and have observed that at 12 months of treatment with NA, $89.4 \%$ of HBeAg-negative and $80 \%$ of HBeAg-positive patients negativize the viral load. This proportion increases to $100 \%$ in both groups at month 18 . In other studies conducted in real clinical practice with chronic hepatitis B patients, overall viral load negativization rates at 12 months in patients treated with tenofovir ranged from 59.2 to $91.9 \%$ [24, 25, 47, 49-51]; and with entecavir, from 41 to $89.4 \%$ [21-23, 51-62]. These differences between the studies are possibly due to the diverse populations studied in each case, the different sensitivity of the PCR used to detect viral load, and to the fact that, in many studies, patients previously treated with other treatments for HBV are included. None of these studies do, however, mention HBV genotyping.

Table 2 compares those other studies that do analyze the response to treatment, as ALT normalization and viral load undetectability, according to HBV genotype. Among the few available studies, it stands out one conducted by Ono et al. [22], where genotype C predominates (70.9\%), and the proportion of patients with undetectable viral load after one year of treatment is $88 \%$, similar to that of our work. In the study of Zoutendijk [23], where genotype D predominates in non-cirrhotic patients (49\%), 68\% of patients have undetectable viral load after one year. Due to the relatively small number of patients included in these studies, no clear conclusions can be drawn about a faster response to treatment in patients with one genotype or another. Although these data may suggest that patients with genotypes $C$ and $E$ respond faster to treatment with nucleos(t)ide analogues than those with genotype $D$.

Regarding normalization of transaminase levels, in the present study rates were 42.1 and $85.7 \%$ after one year in $\mathrm{HBeAg-negative} \mathrm{and} \mathrm{HBeAg}$-positive patients respectively. These percentages reached $55.6 \%$ in $\mathrm{HBeAg}$-negative and $100 \%$ in $\mathrm{HBeAg}$-positive patients at 18 months of follow up. In other studies of actual clinical practice, the percentage of patients with normal transaminases at 12 months ranged from 34.6-95.5\% [21-25, 47, 49-53, 56-60, 62]. These discrepant results may be explained by the different cutoff points taken for normal ALT in the different studies, and by the different stages of hepatopathy of the included patients, since in some cases they include patients with established cirrhosis and even with hepatocarcinoma.

HBeAg loss occurred in $85.7 \%$ of patients in a median time of 31.8 months. Seroconversion rate during the first year was $12.5 \%$. Although there are few HBeAg-positive patients in our study, these results are similar to those found in other published works where these rates oscillate between 8 and 16\% [22, 24, 53, 55, 61].These studies also show that HBeAg-loss rates increase significantly after more than 3 years of treatment. In these works, like in ours, no HBsAg loss is observed.

It should be noted the high adherence to treatment observed in our study: $86.7 \%$ in the first year and almost $100 \%$ in the second year. Among migrants this may be especially striking, since many are the reasons that hamper their compliance and follow-up (labour mobility, visits to their home countries, barriers to access to health care systems, etc.). The reasons for such good adherence are probably related to the collaboration of mediators and community health agents, the use of cost-free drugs, and the lack of barriers to access to the public health care system, either primary or specialized care, as is established in Andalusia, our administrative region.

The main limitation of this study is that the number of patients is not very high, although figures are according to the scarce published studies that describe the response to treatment of genotype $\mathrm{E}$ chronic hepatitis $\mathrm{B}$ patients, either with interferon or with nucleos $(\mathrm{t})$ ide analogues [12, $32,34,35]$. It would have also been interesting to compare patients with genotype $\mathrm{E}$ with other patients of similar origin and socioeconomic circumstances but with different genotypes. In relation to this last aspect, the number of African migrants that we deal with harbouring other genotypes is so low that does not allow valid comparisons. One last limitation is that therapeutic drug monitoring and HBsAg quantification were not available in our hospital, even though the role of the last one during therapy with oral NA is still debatable.

Nevertheless, studies like ours, that shed light on the response of $\mathrm{CHB}$ to different antiviral treatments depending on the genotype, are relevant. This is especially true in the case of relatively unknown genotypes like genotype $\mathrm{E}$, a genotype associated to immune scape mutations [26] and whose epidemiological impact is steadily increasing in the Western world due to migration from Africa. Improving our knowledge on $\mathrm{CHB}$ genotype $\mathrm{E}$ infection and its response to treatment is critical to issue proper and specific recommendations. In addition, although access to NA in Africa is currently difficult, all evidence gathered is useful with a view to future 


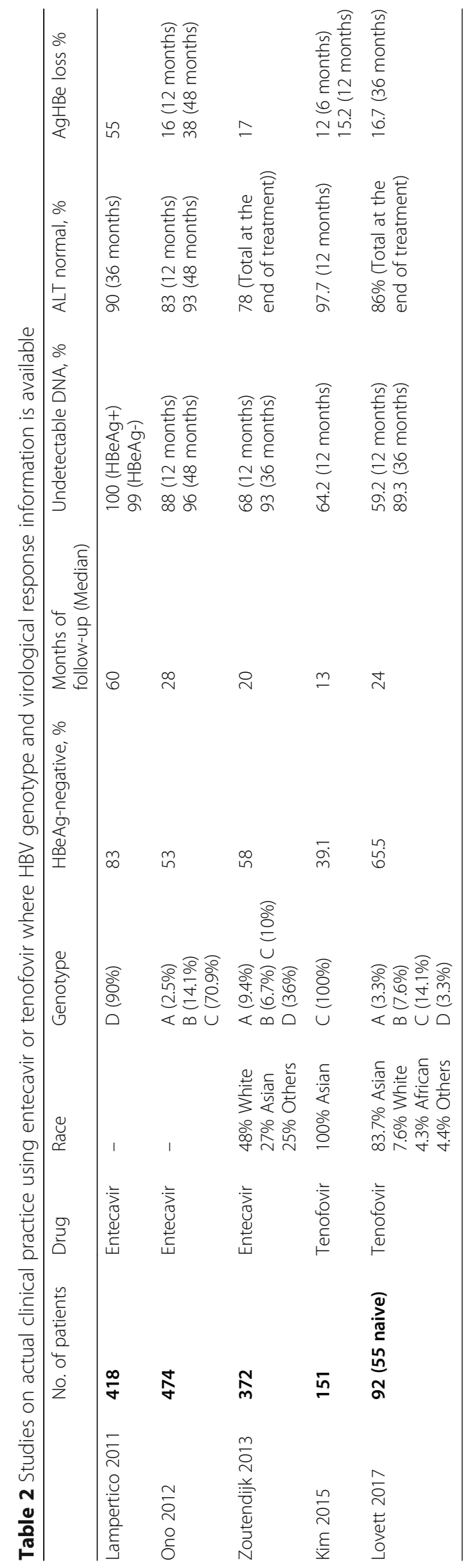


strategies for the treatment and prevention of this disease in the countries of origin. May our work then be considered a small and humble contribution to HBV infection clinical care research.

\section{Conclusions}

As shown in this real practice study, treatment with nucleos(t)ide analogues is safe and effective in sub-Saharan migrants with $\mathrm{CHB}$ genotype $\mathrm{E}$ infection. However, direct comparison studies seem to be necessary to conclude whether there are significant differences in the response to treatment when compared to other HBV genotypes.

Migration is altering geographical distribution of HBV genotypes around the world making considering the clinical and epidemiological implications of less known HBV genotypes, such as genotype E, critical in order to provide proper tailored care.

In our setting, where health care and antiviral drugs are cost-free and available with no barriers, high rates of adherence to treatment can be achieved. But these results could also be transferable to low- and middle-income African populations if therapy with such drugs were to be generally available in the future, contributing to research into a neglected disease that affects a large part of the population living in the poorest regions of the world.

\section{Abbreviations \\ ALP: Alkaline phosphatase; ALT: Alanine aminotransferase; anti-HBc: Hepatitis B core antibody; anti-HBe: Hepatitis B envelope antibody; anti-HBs: Hepatitis B surface antibody; AST: Aspartate aminotransferase; CHB: Chronic Hepatitis B; Cl: Confidence interval; GGT: Gammaglutamyl transferase; HBeAg: Hepatitis B envelope antigen; HBsAg: Hepatitis B surface antigen; HBV: Hepatitis B virus; HCV: Hepatitis C virus; HIV: Human immunodeficiency virus; INF/PEG- INF: Interferon/pegylated-interferon; IQR: Interquartile range; NA: Nucleos(t)ide analogues; PCR: Polymerase chain reaction; SD: Standard deviation; TMU: Tropical Medicine Unit}

\section{Acknowledgements}

The authors thank $\mathrm{M}^{\mathrm{a}}$ Carmen Olvera Porcel, technician in Research Methodology and Biostatistics from FIBAO, for providing invaluable support for the statistical analysis of the data.

\section{Funding}

This study has been funded by RICET (Red de Investigación Cooperativa en Enfermedades Tropicales, -Cooperative Investigation Network for Tropical Diseases-; Exp. N.: RD16/0027/0013), Instituto de Salud Carlos III, and cofinanced by the European Regional Development Fund of the European Union.

This study has been conducted within the activities developed by the research group PAIDI CTS 582 of the regional Ministry of Gender, Health and Social Policy of the Government of Andalusia, RICET and CEMyRI (Center for the Study of Migration and Intercultural Relations of the University of Almeria, Spain).

\section{Availability of data and materials}

The dataset used and analysed during the current study is available from the corresponding author on reasonable request.

\section{Authors' contributions}

Conceptualization and study design: JSC, JACG MTCF, MEE. Investigation: JSC, MTCF, MEE, JACG. Project collaboration: JSC, JACG, MTCF, MEE, ABLS, JW MJSP, ICB. Supervision: JSC, JW, MJSP. Writing - original draft: JACG, JSC, ABLS. Writing - review \& editing: JSC, JACG, MTCF, MEE, ABLS, JW, MJSP, ICB. All authors read and approved the final manuscript.

\section{Ethics approval and consent to participate}

This study received approval and consent from the competent Institutional Review Board, namely, Comité de Ética de la Investigación de Almería (Ethics Research Committee of Almeria) on the 1st January 2017, protocol number EPA-E-JAC-2016 version 1. The need for consent was deemed unnecessary by this IRB because the study was carried out within usual clinical practice.

\section{Consent for publication}

Not applicable.

\section{Competing interests}

JSC participated on one advisory board for Gilead Sciences and received travel grants from Gilead Sciences and Bristol-Myers Squibb. ABLS participated on advisory boards for Bristol-Myers Squibb, and reports travel funding, educational grants and speaker fees from GlaxoSmithKline (ViiV Healthcare), Gilead Sciences, Tibotec (Janssen) Therapeutics, Abbie, Merck Sharp and Dohme, Boehringerlngelheim, Roche Pharma, Pfizer, and Bristol-Myers Squibb. JACG, MJSP and JW received travel grants from Gilead Sciences. MEE received speaker fees and/or travel funding from Gilead Sciences, Bristol-Myers Squibb, Abbie, Merck Sharp and Dohme. All other authors declare no competing interests.

\section{Publisher's Note}

Springer Nature remains neutral with regard to jurisdictional claims in published maps and institutional affiliations.

\section{Author details}

Tropical Medicine Unit, Hospital de Poniente, Carretera de Almerimar s/n, PD: 07400 Almería, El Ejido, Spain. ${ }^{2}$ Tropical Medicine Unit, Distrito Poniente, Almería, Spain. ${ }^{3}$ Digestive Service, Hospital de Poniente, Almería, El Ejido, Spain

Received: 11 August 2018 Accepted: 31 October 2018

Published online: 14 November 2018

References

1. WHO. Hepatitis B: WHO; 2018 [cited 2018 10-08-2018]. Available from: http://www.who.int/mediacentre/factsheets/fs204/es/.

2. O'Hara GA, McNaughton AL, Maponga T, Jooste P, Ocama P, Chilengi R, et al. Hepatitis B virus infection as a neglected tropical disease. PLoS Negl Trop Dis. 2017;11(10):e0005842.

3. WHO. Global hepatitis report, 2017. In: WHO; 2017.

4. Shi W, Zhang Z, Ling C, Zheng W, Zhu C, Carr MJ, et al. Hepatitis B virus subgenotyping: history, effects of recombination, misclassifications, and corrections Infection, genetics and evolution. Journal of molecular epidemiology and evolutionary genetics in infectious diseases. 2013;16:355-61.

5. Rajoriya N, Combet C, Zoulim F, Janssen HLA. How viral genetic variants and genotypes influence disease and treatment outcome of chronic hepatitis B. time for an individualised approach? J Hepatol. 2017;67(6):1281-97.

6. Zhang HW, Yin JH, Li YT, Li CZ, Ren H, Gu CY, et al. Risk factors for acute hepatitis $B$ and its progression to chronic hepatitis in Shanghai, China. Gut. 2008;57(12):1713-20.

7. Mayerat C, Mantegani A, Frei PC. Does hepatitis B virus (HBV) genotype influence the clinical outcome of HBV infection? J Viral Hepat. 1999;6(4):299-304.

8. Kobayashi M, Arase Y, Ikeda K, Tsubota A, Suzuki Y, Saitoh S, et al. Clinical characteristics of patients infected with hepatitis $B$ virus genotypes $a, B$, and C. J Gastroenterol. 2002:37(1):35-9.

9. Suzuki Y, Kobayashi M, Ikeda K, Suzuki F, Arfase Y, Akuta N, et al. Persistence of acute infection with hepatitis $B$ virus genotype a and treatment in Japan. J Med Virol. 2005;76(1):33-9.

10. Chu CJ, Hussain M, Lok AS. Hepatitis B virus genotype B is associated with earlier $\mathrm{HBeAg}$ seroconversion compared with hepatitis B virus genotype $C$. Gastroenterology. 2002;122(7):1756-62.

11. Livingston SE, Simonetti JP, Bulkow LR, Homan CE, Snowball MM, Cagle HH, et al. Clearance of hepatitis $B$ e antigen in patients with chronic hepatitis $B$ and genotypes a, B, C, D, and F. Gastroenterology. 2007;133(5):1452-7.

12. Westland C, Delaney WT, Yang H, Chen SS, Marcellin P, Hadziyannis S, et al. Hepatitis B virus genotypes and virologic response in 694 patients in phase III studies of adefovir dipivoxil1. Gastroenterology. 2003;125(1):107-16. 
13. Yu MW, Yeh SH, Chen PJ, Liaw YF, Lin CL, Liu CJ, et al. Hepatitis B virus genotype and DNA level and hepatocellular carcinoma: a prospective study in men. J Natl Cancer Inst. 2005;97(4):265-72.

14. Kao JH, Chen PJ, Lai MY, Chen DS. Clinical and virological aspects of blood donors infected with hepatitis B virus genotypes B and C. J Clin Microbiol. 2002;40(1):22-5.

15. Yousif M, Mudawi H, Bakhiet S, Glebe D, Kramvis A. Molecular characterization of hepatitis B virus in liver disease patients and asymptomatic carriers of the virus in Sudan. BMC Infect Dis. 2013;13:328.

16. Chu CM, Liaw YF. Genotype C hepatitis B virus infection is associated with a higher risk of reactivation of hepatitis $B$ and progression to cirrhosis than genotype B: a longitudinal study of hepatitis B e antigen-positive patients with normal aminotransferase levels at baseline. J Hepatol. 2005;43(3):411-7.

17. Sanchez-Tapias JM, Costa J, Mas A, Bruguera M, Rodes J. Influence of hepatitis B virus genotype on the long-term outcome of chronic hepatitis B in western patients. Gastroenterology. 2002;123(6):1848-56.

18. Livingston SE, Simonetti JP, McMahon BJ, Bulkow LR, Hurlburt KJ, Homan CE, et al. Hepatitis B virus genotypes in Alaska native people with hepatocellular carcinoma: preponderance of genotype F. J Infect Dis. 2007;195(1):5-11.

19. Yang $\mathrm{HI}$, Yeh $\mathrm{SH}$, Chen PJ, lloeje $\mathrm{UH}$, Jen $\mathrm{CL}$, Su J, et al. Associations between hepatitis $\mathrm{B}$ virus genotype and mutants and the risk of hepatocellular carcinoma. J Natl Cancer Inst. 2008;100(16):1134-43.

20. Kew MC, Kramvis A, Yu MC, Arakawa K, Hodkinson J. Increased hepatocarcinogenic potential of hepatitis B virus genotype a in bantuspeaking sub-saharan Africans. J Med Virol. 2005;75(4):513-21.

21. Lampertico PVM, Soffredini R. Entecavir monotherapy for nuc-na€Ive chronic hepatitis B patients from field practice: high efficacy and favorable Osafety profile over 3 year. Hepatology. 2011;54:A1436.

22. Ono A, Suzuki F, Kawamura Y, Sezaki H, Hosaka T, Akuta N, et al. Long-term continuous entecavir therapy in nucleos(t)ide-naive chronic hepatitis $B$ patients. J Hepatol. 2012;57(3):508-14.

23. Zoutendijk R, Reijnders JG, Zoulim F, Brown A, Mutimer DJ, Deterding K, et al. Virological response to entecavir is associated with a better clinical outcome in chronic hepatitis B patients with cirrhosis. Gut. 2013;62(5):760-5.

24. Kim JH, Jung SW, Byun SS, Shin JW, Park BR, Kim MH, et al. Efficacy and safety of tenofovir in nucleos(t)ide-naive patients with genotype $\mathrm{C}$ chronic hepatitis B in real-life practice. Int J Clin Pharm. 2015;37(6):1228-34.

25. Lovett GC, Nguyen T, Iser DM, Holmes JA, Chen R, Demediuk B, et al. Efficacy and safety of tenofovir in chronic hepatitis B: Australian real world experience. World J Hepatol. 2017;9(1):48-56.

26. Malagnino V, Salpini R, Maffongelli G, Battisti A, Fabeni L, Piermatteo L, et al. High rates of chronic HBV genotype $E$ infection in a group of migrants in Italy from West Africa: Virological characteristics associated with poor immune clearance. PLoS One. 2018;13(3):e0195045.

27. Archampong TN, Boyce CL, Lartey M, Sagoe KW, Obo-Akwa A, Kenu E, et al. HBV genotypes and drug resistance mutations in antiretroviral treatmentnaive and treatment-experienced HBV-HIV-coinfected patients. Antivir Ther 2017;22(1):13-20

28. Boyd A, Maylin S, Moh R, Mahjoub N, Gabillard D, Eholie SP, et al. Hepatitis $B$ surface antigen quantification as a predictor of seroclearance during treatment in HIV-hepatitis B virus coinfected patients from sub-Saharan Africa. J Gastroenterol Hepatol. 2016;31(3):634-44.

29. Boyd A, Moh R, Gabillard D, le Carrou J, Danel C, Anglaret X, et al. Low risk of lamivudine-resistant HBV and hepatic flares in treated HIV-HBV-coinfected patients from cote d'Ivoire. Antivir Ther. 2015;20(6):643-54.

30. Honge BL, Jespersen S, Medina C, Te Dda S, da Silva ZJ, Lewin S, et al. Hepatitis B and Delta virus are prevalent but often subclinical co-infections among HIV infected patients in Guinea-Bissau, West Africa: a cross-sectional study. PLoS One. 2014;9(6):e99971.

31. De Francesco MA, Gargiulo F, Spinetti A, Zaltron S, Giagulli C, Caccuri F, et al. Clinical course of chronic hepatitis B patients receiving nucleos(t)ide analogues after virological breakthrough during monotherapy with lamivudine. The new microbiologica. 2015;38(1):29-37.

32. Boglione L, Cardellino CS, De Nicolo A, Cariti G, Di Perri G, D'Avolio A. Different HBsAg decline after 3 years of therapy with entecavir in patients affected by chronic hepatitis B HBeAg-negative and genotype a, D and E. J Med Virol. 2014;86(11):1845-50.

33. Boglione L, Cariti G, Ghisetti V, Burdino E, Di Perri G. Extended duration of treatment with peginterferon alfa-2a in patients with chronic hepatitis $B$, HBeAg-negative and E genotype: a retrospective analysis. J Med Virol. 2018; 90(6):1047-52
34. Boglione L, Cusato J, Cariti G, Di Perri G, D'Avolio A. The E genotype of hepatitis B: clinical and virological characteristics, and response to interferon. The Journal of infection. 2014;69(1):81-7.

35. Erhardt A, Gobel T, Ludwig A, Lau GK, Marcellin P, van Bommel F, et al. Response to antiviral treatment in patients infected with hepatitis $B$ virus genotypes E-H. J Med Virol. 2009;81(10):1716-20.

36. Terrault NA, Lok ASF, McMahon BJ, Chang KM, Hwang JP, Jonas MM, et al Update on prevention, diagnosis, and treatment of chronic hepatitis B: AASLD 2018 hepatitis B guidance. Hepatology. 2018;67(4):1560-99.

37. Coppola N, Alessio L, Gualdieri L, Pisaturo M, Sagnelli C, Minichini C, et al. Hepatitis B virus infection in undocumented immigrants and refugees in southern Italy: demographic, virological. and clinical features Infectious diseases of poverty. 2017;6(1):33.

38. Ott JJ, Stevens GA, Groeger J, Wiersma ST. Global epidemiology of hepatitis $B$ virus infection: new estimates of age-specific HBsAg seroprevalence and endemicity. Vaccine. 2012;30(12):2212-9.

39. Cuenca-Gomez JA, Salas-Coronas J, Soriano-Perez MJ, Vazquez-Villegas J, Lozano-Serrano AB, Cabezas-Fernandez MT. Viral hepatitis and immigration: a challenge for the healthcare system. Revista clinica espanola. 2016;216(5):248-52.

40. European Association For The Study Of The L. EASL clinical practice guidelines: management of chronic hepatitis B. J Hepatol. 2009;50(2):227-42.

41. European Association For The Study Of The L. EASL clinical practice guidelines: management of chronic hepatitis B virus infection. J Hepatol. 2012;57(1):167-85

42. Terrault NA, Bzowej NH, Chang KM, Hwang JP, Jonas MM, Murad MH, et al. AASLD guidelines for treatment of chronic hepatitis B. Hepatology. 2016; 63(1):261-83.

43. Bedossa P, Poynard T. An algorithm for the grading of activity in chronic hepatitis C. The METAVIR Cooperative Study Group Hepatology. 1996;24(2): 289-93.

44. Botha JF, Ritchie MJ, Dusheiko GM, Mouton HW, Kew MC. Hepatitis B virus carrier state in black children in Ovamboland: role of perinatal and horizontal infection. Lancet. 1984;1(8388):1210-2.

45. Kew MC. Hepatocellular carcinoma in African blacks: recent progress in etiology and pathogenesis. World J Hepatol. 2010;2(2):65-73.

46. Stasi C, Silvestri C, Voller F, Cipriani F. The epidemiological changes of HCV and HBV infections in the era of new antiviral therapies and the anti-HBV vaccine. Journal of infection and public health. 2016:9(4):389-95.

47. Marcellin P, Zoulim F, Hezode C, Causse X, Roche B, Truchi R, et al. Effectiveness and safety of Tenofovir Disoproxil fumarate in chronic hepatitis B: a 3-year, prospective, real-world study in France. Dig Dis Sci. 2016;61(10):3072-83.

48. Raimondi S, Maisonneuve P, Bruno S, Mondelli MU. Is response to antiviral treatment influenced by hepatitis B virus genotype? J Hepatol. 2010;52(3):441-9.

49. Petersen J, Heyne R, Mauss S, Schlaak J, Schiffelholz W, Eisenbach C, et al. Effectiveness and safety of Tenofovir Disoproxil fumarate in chronic hepatitis B: a 3-year prospective field practice study in Germany. Dig Dis Sci. 2016;61(10):3061-71.

50. Ahn HJ, Song MJ, Jang JW, Bae SH, Choi JY, Yoon SK. Treatment efficacy and safety of Tenofovir-based therapy in chronic hepatitis B: a real life cohort study in Korea. PLoS One. 2017;12(1):e0170362.

51. Pereira CV, Tovo CV, Grossmann TK, Mirenda H, Dal-Pupo BB, Almeida PR, et al. Efficacy of entecavir and tenofovir in chronic hepatitis B under treatment in the public health system in southern Brazil. Memorias do Instituto Oswaldo Cruz. 2016:111(4):252-7.

52. Buti M, Morillas RM, Prieto M, Diago M, Perez J, Sola R, et al. Efficacy and safety of entecavir in clinical practice in treatment-naive Caucasian chronic hepatitis B patients. Eur J Gastroenterol Hepatol. 2012;24(5):535-42.

53. Hou JL, Jia JD, Wei L, Zhao W, Wang YM, Cheng M, et al. Efficacy and safety of entecavir treatment in a heterogeneous CHB population from a 'realworld' clinical practice setting in China. J Viral Hepat. 2013;20(11):811-20.

54. Ridruejo E, Marciano S, Galdame O, Reggiardo MV, Munoz AE, Adrover R, et al. Efficacy and safety of long term entecavir in chronic hepatitis B treatment naive patients in clinical practice. Ann Hepatol. 2014;13(3):327-36.

55. Liu A, Ha NB, Lin B, Yip B, Trinh HN, Nguyen HA, et al. Low hepatitis B envelope antigen seroconversion rate in chronic hepatitis $B$ patients on long-term entecavir $0.5 \mathrm{mg}$ daily in routine clinical practice. Eur J Gastroenterol Hepatol. 2013:25(3):338-43.

56. Luo J, Li X, Wu Y, Lin G, Pang Y, Zhang X, et al. Efficacy of entecavir treatment for up to 5 years in nucleos(t)ide-naive chronic hepatitis B patients in real life. Int J Med Sci. 2013;10(4):427-33. 
57. Wang CC, Tseng KC, Peng CY, Hsieh TY, Lin CL, Su TH, et al. Viral load and alanine aminotransferase correlate with serologic response in chronic hepatitis B patients treated with entecavir. J Gastroenterol Hepatol. 2013;28(1):46-50.

58. Yuen MF, Seto WK, Fung J, Wong DK, Yuen JC, Lai CL. Three years of continuous entecavir therapy in treatment-naive chronic hepatitis B patients: VIRAL suppression, viral resistance, and clinical safety. Am J Gastroenterol. 2011;106(7):1264-71.

59. Ahn J, Lee HM, Lim JK, Pan CQ, Nguyen MH, Ray Kim W, et al. Entecavir safety and effectiveness in a national cohort of treatment-naive chronic hepatitis B patients in the US - the ENUMERATE study. Aliment Pharmacol Ther. 2016;43(1):134-44.

60. Pawlowska M, Domagalski K, Smok B, Rajewski P, Wietlicka-Piszcz M, Halota W, et al. Continuous up to 4 years Entecavir treatment of HBV-infected adolescents - a longitudinal study in real life. PLoS One. 2016;11(9):e0163691.

61. Carey INH, Joe D. Denovo antiviral therapy with nucleos(t)ide analogues in 'real-life' patients with chronic hepatitis B infection: comparison of virological response between lamivudine + adefovir, entecavir vs. tenofovir therapy. Hepatology. 2011;54:A1396

62. Baqai SFYD, Gish RG. Profound virologic response in chronic hepatitis B (CHB) patients treated with entecavir (ETV) in HBeAg positive and negative disease. Hepatology. 2009;50(\$4):530A.

Ready to submit your research? Choose BMC and benefit from:

- fast, convenient online submission

- thorough peer review by experienced researchers in your field

- rapid publication on acceptance

- support for research data, including large and complex data types

- gold Open Access which fosters wider collaboration and increased citations

- maximum visibility for your research: over $100 \mathrm{M}$ website views per year

At BMC, research is always in progress.

Learn more biomedcentral.com/submissions 